\title{
An international phase iii randomised trial on the efficacy of helium/oxygen during spontaneous breathing and intermittent non-invasive ventilation for severe exacerbations of chronic obstructive pulmonary disease (the E.C.H.O. ${ }^{\mathrm{IC}}$ trial)
}

\author{
P Jolliet ${ }^{1 *}$, L Besbes², F Abroug², J Ben Kheli ${ }^{3}$, M Besbes $^{3}$, J-M Arnal ${ }^{4}$, F Daviaud $^{5}$, J-D Chiche ${ }^{5}$, B Lortat-Jacob ${ }^{6}$, \\ J-L Diehl ${ }^{6}$, N Lerolle ${ }^{7}$, A Mercat $^{7}$, K Razazi $^{8}$, C Brun-Buisson $^{8}$, S Bertini ${ }^{9}$, A Corrado ${ }^{9}$, J Texereau ${ }^{10}$, L Brochard ${ }^{11}$
}

From ESICM LIVES 2015

Berlin, Germany. 3-7 October 2015

\section{Introduction}

Due to its reduced density, Helium/Oxygen $\left(\mathrm{He} / \mathrm{O}_{2}\right)$ reduces the work of breathing, intrinsic PEEP and hypercapnia more than Air $/ \mathrm{O}_{2}$ during non-invasive ventilation (NIV) in COPD exacerbations [1,2]. Two prospective, randomized multicenter trials were inconclusive in showing a benefit of $\mathrm{He} / \mathrm{O}_{2} \mathrm{NIV}$ on outcome (intubation, mortality, length of stay (LOS) in ICU) but were potentially underpowered $[3,4]$.

\section{Objectives}

To evaluate whether 72-hr continuous $\mathrm{He} / \mathrm{O}_{2}$ during both spontaneous breathing and NIV is superior to Air/ $\mathrm{O}_{2}$ in reducing NIV failure (intubation or mortality during ICU stay) in severe hypercapnic COPD exacerbations. Secondary outcomes included physiological parameters, duration of ventilation, ICU and hospital LOS, 6-month recurrence and rehospitalization rates.

\section{Methods}

Prospective, randomized multicenter (16 centers in 6 countries) trial, comparing the two gas mixtures for a maximum of 72 hours. Hypothesis was that $\mathrm{He} / \mathrm{O}_{2}$ would reduce intubation rate from $25 \%$ to $15 \%$, resulting in a total sample size of 670 patients. Spontaneous breathing and NIV were applied with specific devices for $\mathrm{He} / \mathrm{O}_{2}$. Same ventilator was used in both arms.

\section{Results}

The trial was stopped prematurely for futility (low intubation rate reported by the adjudication committee). 445 patients were included (mean \pm SD $68 \pm 11$ yrs; M:F 69:31\%; BMI $26 \pm 6 \mathrm{~kg} / \mathrm{m}^{2}$; SAPS $349 \pm 8$; Resp rate (RR) $29 \pm 6 / \mathrm{min}-\mathrm{PaO}_{2} 75 \pm 36 \mathrm{mmHg} ; \mathrm{PaCO}_{2}$ $69 \pm 16 \mathrm{mmHg} ; \mathrm{pH} 7.30 \pm 0.06$ - intention-to-treat data set), with no baseline difference between $\mathrm{He} / \mathrm{O}_{2}$ vs. Air/ $\mathrm{O}_{2}$. The primary outcome was negative (Figure 1) and baseline $\mathrm{pH}$ was the only significant predictor of NIV failure. NIV failure occurred in the first 72 hours (while receiving the study treatment) in $58 \%$ of failures with $\mathrm{He} / \mathrm{O}_{2}$ and $84 \%$ with Air $/ \mathrm{O}_{2}(\mathrm{p}=0.97)$. RR (Figure 2), $\mathrm{pH}, \mathrm{PaCO}_{2}$ and encephalopathy improved faster and with greater magnitude with $\mathrm{He} / \mathrm{O}_{2}$

\section{Conclusions}

NIV failure rate was not reduced by $\mathrm{He} / \mathrm{O}_{2}$ administered during NIV and spontaneous breathing for up to $72 \mathrm{hrs}$. Failure rate was low in both groups, reflecting the current efficacy of NIV in decompensated COPD. However, $\mathrm{He} / \mathrm{O}_{2}$ led to improved physiological response, thus confirming previous results, and a shorter duration of invasive ventilation and ICU stay in patients with NIV failure.

\section{Grant Acknowledgment}

ClinicalTrials.gov Identifier: NCT01155310. Study funded by Air Liquide Healthcare.

${ }^{1}$ Intensive Care and Burn Unit - CHUV, Lausanne, Switzerland

Full list of author information is available at the end of the article 


\begin{tabular}{|l|l|l|c|}
\hline Mean \pm SD & $\mathrm{Air} / \mathrm{O}_{2}(220 \mathrm{pts})$ & $\mathrm{He} / \mathrm{O}_{2}(225 \mathrm{pts})$ & $\mathrm{p}$ \\
\hline NIV failure $n(\%)$ & $32(14.5)$ & $33(14.7)$ & 0.97 \\
\hline $\begin{array}{l}\text { Cumulative duration of invasive } \\
\text { ventilation after NIV failure } d\end{array}$ & $13.6 \pm 12.6$ & $7.4 \pm 7.6$ & 0.02 \\
\hline LOS in ICU -all pts $d$ & $8.7 \pm 6.7$ & $10.1 \pm 11.6$ & $\mathrm{NS}$ \\
\hline LOS in ICU after NIV failure $d$ & $26.7 \pm 21.0$ & $15.8 \pm 10.9$ & 0.01 \\
\hline ICU mortality all pts $n(\%)$ & $14(6.4)$ & $12(5.3)$ & $\mathrm{NS}$ \\
\hline 6-mo. mortality $n(\%)$ & $35(15.9)$ & $42(17.8)$ & $\mathrm{NS}$ \\
\hline
\end{tabular}

Figure 1

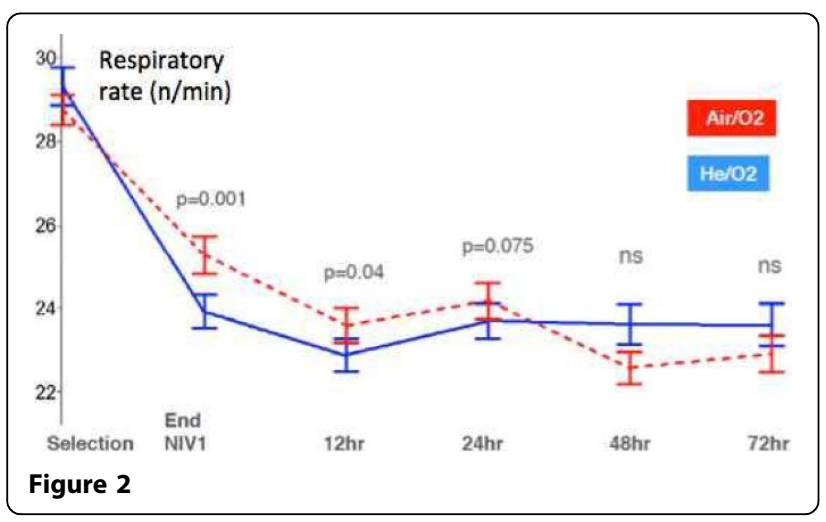

\section{Authors' details}

${ }^{1}$ Intensive Care and Burn Unit - CHUV, Lausanne, Switzerland. ${ }^{2}$ Fattouma Bourguiba University Hospital, Ariana, Tunisia. ${ }^{3}$ Abderrahmen Mami Hospital, Monastir, Tunisia. ${ }^{4}$ Font-Pré Hospital, Toulon, France. ${ }^{5}$ Cochin Hospital, Paris, France. ${ }^{6}$ Georges Pompidou European Hospital, Paris, France. ${ }^{7}$ Angers University Hospital, Angers, France. ${ }^{8}$ Henri-Mondor Hospital, Paris, France. ${ }^{9}$ Careggi University Hospital, Florence, Italy. ${ }^{10}$ Air Liquide Santé International, Paris, France. ${ }^{11}$ St Michael's Hospital-University Toronto, Toronto, Canada.

Published: 1 October 2015

\section{References}

1. Jaber S, Fodil R, Carlucci A, Boussarsar M, Pigeot J, Lemaire F, et al: Noninvasive ventilation with helium-oxygen in acute exacerbations of chronic obstructive pulmonary disease. Am J Respir Crit Care Med 2000, 161:1191-1200.

2. Jolliet P, Tassaux D, Thouret JM, Chevrolet JC: Beneficial effects of helium: oxygen versus air:oxygen noninvasive pressure support in patients with decompensated chronic obstructive pulmonary disease. Crit Care Med 1999, 27(11):2422-2429.

3. Jolliet P, Tassaux D, Roeseler J, Burdet L, Broccard A, D'Hoore W, et al: Helium-oxygen versus air-oxygen noninvasive pressure support in decompensated chronic obstructive disease: A prospective, multicenter study. Crit Care Med 2003, 31(3):878-884.

4. Maggiore SM, Richard JC, Abroug F, Diehl JL, Antonelli M, Sauder P, et al: A multicenter, randomized trial of noninvasive ventilation with heliumoxygen mixture in exacerbations of chronic obstructive lung disease. Crit Care Med 2010, 38(1):145-151.

doi:10.1186/2197-425X-3-S1-A422

Cite this article as: Jolliet et al:: An international phase iii randomised trial on the efficacy of helium/oxygen during spontaneous breathing and intermittent non-invasive ventilation for severe exacerbations of chronic obstructive pulmonary disease (the E.C.H.O. ${ }^{\mathrm{CU}}$ trial). Intensive Care Medicine Experimental 2015 3(Suppl 1):A422.

\section{Submit your manuscript to a SpringerOpen ${ }^{\circ}$ journal and benefit from:}

- Convenient online submission

- Rigorous peer review

- Immediate publication on acceptance

- Open access: articles freely available online

- High visibility within the field

- Retaining the copyright to your article

Submit your next manuscript at $>$ springeropen.com 